\title{
Simplified correction of a meningomyelocele-like defect in the ovine fetus ${ }^{1}$
}

\author{
Correção simplificada de um defeito semelhante à meningomielocele em fetos de ovelha
}

\author{
Rogério Chaccur Abou-Jamra', Paulo Roberto Valente" ${ }^{\mathrm{II}}$, Andrezza Araújo ${ }^{\mathrm{III}}$, Rita de Cássia Sanchez e Oliveira ${ }^{\mathrm{IV}}$, Paulo Hilário \\ Saldiva $^{\mathrm{V}}$, Denise Araújo Lapa Pedreira ${ }^{\mathrm{VI}}$
}

${ }^{\mathrm{I}}$ Fellow PhD degree (in memoriam), Pathology Department, Faculty of Medicine, USP, Sao Paulo, Brazil.

${ }^{\text {II }}$ Veterinarian, Chief, Experimental Surgery Laboratory, IDPC, Sao Paulo, Brazil.

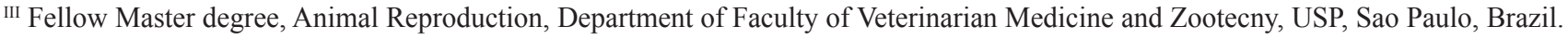

IV PhD, Pathology Department, Faculty of Medicine, USP, Sao Paulo, Brazil.

${ }^{v}$ Chairman, Pathology Department, Faculty of Medicine, USP, Sao Paulo, Brazil.

${ }^{\mathrm{v}} \mathrm{PhD}$, Faculty of Medicine, USP, Sao Paulo, Brazil.

\begin{abstract}
Purpose: To develop a simplified technique for antenatal correction of a meningomyelocele -like defect in fetal sheep to allow direct skin closure. Methods: A spinal defect was surgically created at 75 days of gestation in the fetuses of 36 pregnant sheep, 23 survived the surgery. At 102 days gestation, the defect was corrected in 14 cases (9 were left untreated). Skin surrounding the defect was dissected below the dermis to permit its edges to be approximated and sutured, without interposing any material to its edges. An interface material intended to protect the neural tissue from skin adhesion was used and the skin defect was completely closed over it. Pregnancy was allowed to continue up to 138 days gestation, the fetuses were submitted to macroscopic and microscopic analysis. Results: The defect was successfully corrected in $90.9 \%$ in the experimental group, and spontaneous closure occurred in $22.3 \%$ in the control group $(\mathrm{p}<0.05)$. The survival rate after the creation and correction of the defect was $63.4 \%$ and $78 \%$ respectively. Conclusion: This simplified technique was successful in the correction a meningomyelocele-like defect, in the fetal sheep.
\end{abstract}

Key words: Surgery. Fetal Therapies. Meningomyelocele. Spinal Dysraphism. Disease Models, Animal. Sheep.

\section{RESUMO}

Objetivo: Desenvolver uma técnica simplificada de correção pré-natal de defeito semelhante à mielomeningocele em fetos de ovelha permitindo um fechamento direto da pele. Métodos: Um defeito espinhal foi cirurgicamente criado com 75 dias de gestação, em 36 fetos de ovelha, 23 sobreviveram à cirurgia. Após 102 dias de gestação, o defeito foi corrigido em 14 casos (9 não foram tratados). A pele em volta do defeito foi dissecada abaixo da derme para permitir a aproximação direta das bordas através de sutura, sem a interposição de nenhum material entre a pele. Um material de interface foi colocado entre o tecido neural exposto e a pele, com o objetivo de evitar a adesão da medula à pele, que foi completamente fechada sobre o defeito. A gravidez foi mantida até 138 dias, os fetos foram submetidos a análises macroscópicas e microscópicas. Resultados: O defeito foi corrigido em $90.9 \%$ no grupo experimental, e o fechamento espontâneo ocorreu em $22.3 \%$ no grupo controle $(\mathrm{p}<0.05)$. A taxa de sobrevivência após a criação do defeito e posteriormente a sua correção foi de $63,4 \%$ e $78 \%$, respectivamente. Conclusão: Esta técnica simplificada teve sucesso na correção do defeito semelhante à mielomeningocele em feto de ovelha.

Descritores: Cirurgia. Terapias Fetais. Meningomielocele. Disrafismo Espinal. Modelos Animais de Doenças. Ovinos.

${ }^{1}$ Research performed at the Experimental Surgery Laboratory, Dante Pazzanese Cardiology Institute (IDPC) and Pathology Department, Faculty of Medicine, University of Sao Paulo (USP), Brazil.

\section{Introduction}

Meningomyelocele (MMC) is a congenital defect that affects the brain and spinal cord. It is a common congenital malformation of the central nervous system in humans, and is associated with low fetal/neonatal mortality ${ }^{1}$. Most infants born with MMC develop paraparesis, urinary incontinence, and skeletal deformity. MMC is almost always associated with the Chiari II malformation, which is characterized by herniation of cerebellum and hindbrain, as well as hydrocephalus in most cases, which can cause neurological problems ${ }^{2}$. Fourteen percent of children with MMC die within the first 5 years of life, and $73 \%$ of these deaths are attributable to hindbrain herniation ${ }^{3}$.

The failure to produce satisfactory clinical outcomes with postnatal MMC treatments suggests that better results might be obtained with prenatal treatment ${ }^{3}$. It is believed that early prenatal treatment of MMC could reduce both chemical and mechanical damage to the exposed medulla ${ }^{4}$. A large number of studies using animal models and humans have provided evidences that prenatal 
surgical MMC correction decrease central and peripheral neurologic deterioration improves leg function, reduces hindbrain herniation and consequently shunt-dependent hydrocephalus ${ }^{2-10}$. With this purpose, a randomized prospective trial (the spinabifidamoms trial) is currently being conducted in three centers in the United States to determine if intrauterine repairs of fetal MMC improves outcome in humans ${ }^{11,12}$.

The demonstration that long-term exposure of the open spinal cord to the intrauterine environment can lead to neural tissue damage and subsequent loss of neurological function, suggests that the prenatal closure of the defect can improve neurological outcome. This makes the development of novel prenatal techniques for correcting MMC an important research aim.

With the goal of treating the MMC prenatally in humans an open fetal surgery approach is currently under evaluation. But, open fetal surgery itself can be associated with considerable maternal and fetal morbidity ${ }^{13}$ justifying the pursue to develop of an endoscopic approach to cover the defect.

To endoscopically close the defect, the currently neurosurgical technique used ${ }^{13}$ is difficult to be applied, so our hypothesis is that development of an easy-to-apply MMC would be of benefit. Toward this goal, our group previously developed a simplified technique using a cellulose biomatrix as an interface material in a rabbit model ${ }^{14}$. In the present study, we extend these studies by testing the efficacy of this new technique in an ovine model $^{15}$

Comparing to other techniques found in the literature, we believe ours is more suitable to be applied in the endoscopic closure of fetal spinal bifida.

\section{Methods}

Thirty-six mixed breed Hampshire pregnant sheep were transported from the farm to the laboratory at least seven days before surgery. A 48-hour food and 24-hour fluid fast was used prior surgery. Intra-venous $1 \%$ acepromazine $(0.2-0.4 \mathrm{mg} / \mathrm{kg})$ and midazolam $(0.3-0.5 \mathrm{mg} / \mathrm{kg})$ were used prior to transport the animals to the operating room. Supplemental thiopental $(7.5$ to $10 \mathrm{mg} / \mathrm{kg})$ anesthesia was delivered intravenously and maintained with 2\% halothane. Endovenous enrofloxacin $(5 \mathrm{mg} / \mathrm{kg})$ was used for antibiotic prophylaxis.

\section{Creation of the defect}

After sterile draping, a para-mammary incision was made in the lower maternal abdomen and the uterus was exteriorized. A hysterotomy was performed to expose the fetal lumbar spine. A spinal defect was created at 75 days gestation (range 74-78) using a modified technique from the initially proposed by Meuli et al. ${ }^{16}$ and modified by Paek et al. ${ }^{17}$, that we have previously tested ${ }^{15}$. Briefly, the skin and paraspinal muscles overlying the lumbar portion of the fetal spine were removed to expose a $3 \times 2 \mathrm{~cm}$ area. A laminectomy was then performed and the dura was incised using the tip of a 16gauge neddle to allow a sharp instrument to allow drainage of cerebrospinal fluid. The fetus was then returned to uterine cavity and the uterus was closed with a continuous running suture with mononylon 4-0. Fetal heartbeats were checked, the maternal abdomen was closed and the animals were returned to their pens after they recovered from the anesthesia.

\section{Correction of the defect}

Correction of the defect was performed on average at 102 days of gestation (range 98 - 112 days), (Figure 1A) was made in 14 cases (experimental group), while 9 fetuses remained uncorrected (control group). Using the approach described above, the fetus was partially exposed from the tail to the lumbar region. Skin surrounding the defect was dissected below the dermis to permit the placement of an interface material over the exposed neural tissue below the skin (Figure 1B). The skin was then completely closed over the defect using an interrupted suture (Figure 1C, D). The uterus, maternal abdominal muscle and skin were closed, and pregnancy was allowed to continue to near term.
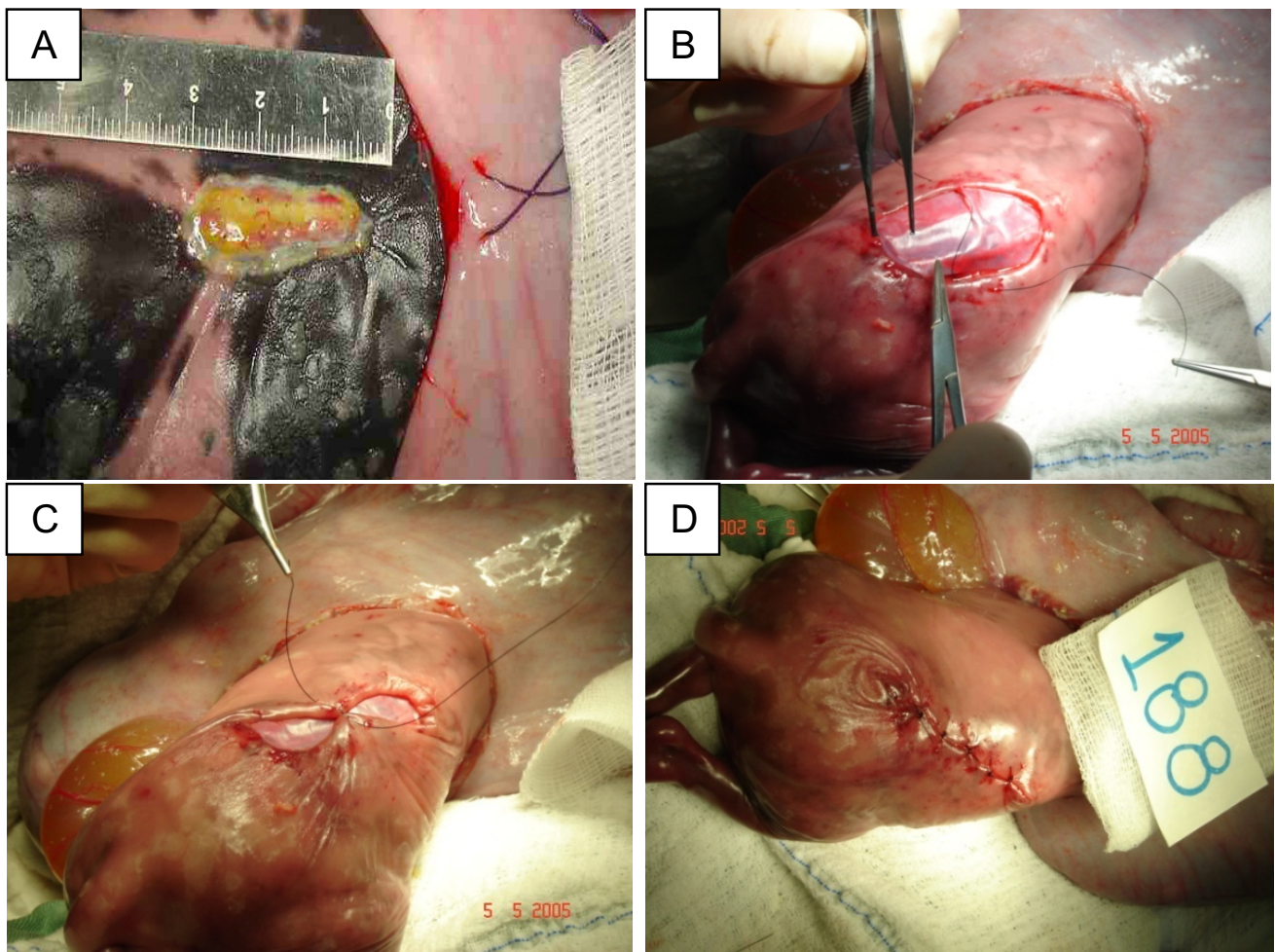

FIGURE 1 -. (A) External aspect of MMC-like defect created at 75 days, after 3 weeks of intrauterine exposure (100 days of gestation), note the striking resemblance of an espina bifida in the human fetus. (B) Skin surrounding defect has been dissected and the interface material is covering the defect. (C) Fetal skin is beginning to be closed. (D) Final aspect of the skin suture 


\section{Results}

Animals were sacrificed on average at 138 days of gestation (ranging from 137 - 145 days) by intravenous injection of $1.5 \mathrm{~g}$ thiopenthal, followed by $20 \mathrm{ml} \mathrm{KCl}$. After maternal death, fetuses were harvested through laparotomy/hysterotomy and were sacrificed by intracardiac potassium chloride injection.

\section{Pathological examination}

Fetuses were photographed and fixed in $10 \%$ formalin. The preserved specimens were subjected to macroscopic and microscopic analysis. Corrections were considered successful when the interface material was completely held in place over the medulla by the healed skin.

This project was approved by the Ethical Committee in Animal Research of Dante Pazzaneze Cardiology Institute. Statistical analysis was performed using Fisher's exact test to compare groups.
The defect was created in 36 fetuses, and 13 died during or after surgery, resulting in an overall survival rate of $63.4 \%$ $(23 / 36)$. Of the 23 surviving fetuses, defects were corrected in 14 cases (experimental group), while 9 fetuses remained uncorrected (control group). Of the 14 fetuses subjected to corrective surgery, 11 survived, corresponding to a survival rate of $78 \%$ (11/14); no deaths occurred in the control group. One maternal death occurred one day post-surgery, presumably due to aspiration of the stomach contents during extubation. Pregnancy ended on average at 133 days of gestation (range: 118-145 days). Spontaneous vaginal preterm birth occurred in 4 cases $(20 \%)$.

\section{Pathological examination}

Macroscopic examination revealed that, in the experimental group, skin was completely closed in 8 out of 11 cases. In 2 out of 9 cases in the control group, partial spontaneous skin healing occurred. The correction was considered successful when the interface material was kept in place by the approximated skin protecting the medulla to the amniotic fluid/mechanical exposure. This occurred in 10 out of 11 cases $(90,9 \%)$ (Figure 2).

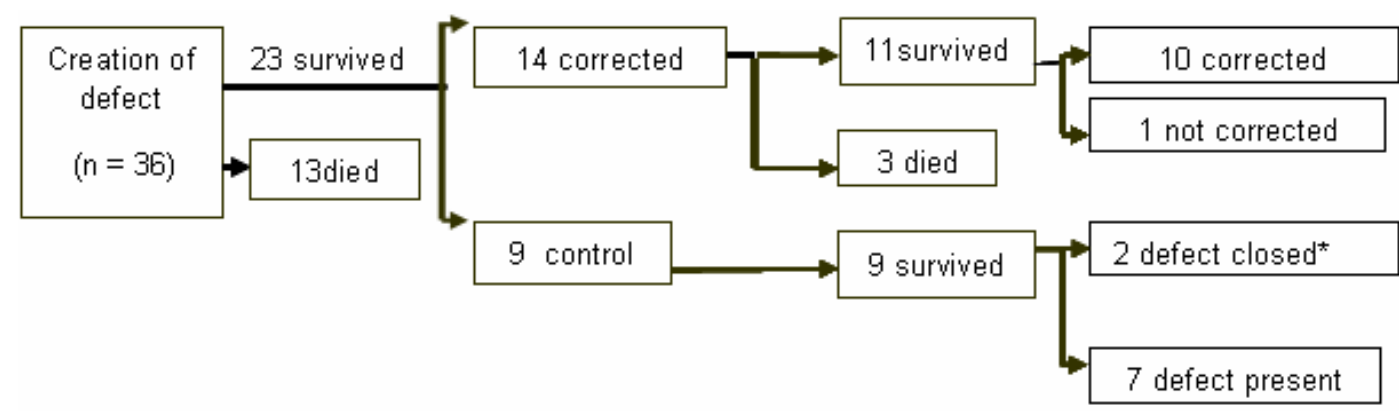

*Spontaneous closure

FIGURE 2 - Survival and success rates after intrauterine creation (75 days) and correction (100 days) of MMC-like defects in fetal sheep

Histological examination of transverse sections of fetal spine confirmed the defect extended to the medulla in all fetuses in both groups. Examination of granuloma tissue scaffolding revealed a scar composed of spindle-shaped fibroblasts and dense collagen in areas of vascular regression (Figure 3B, C).

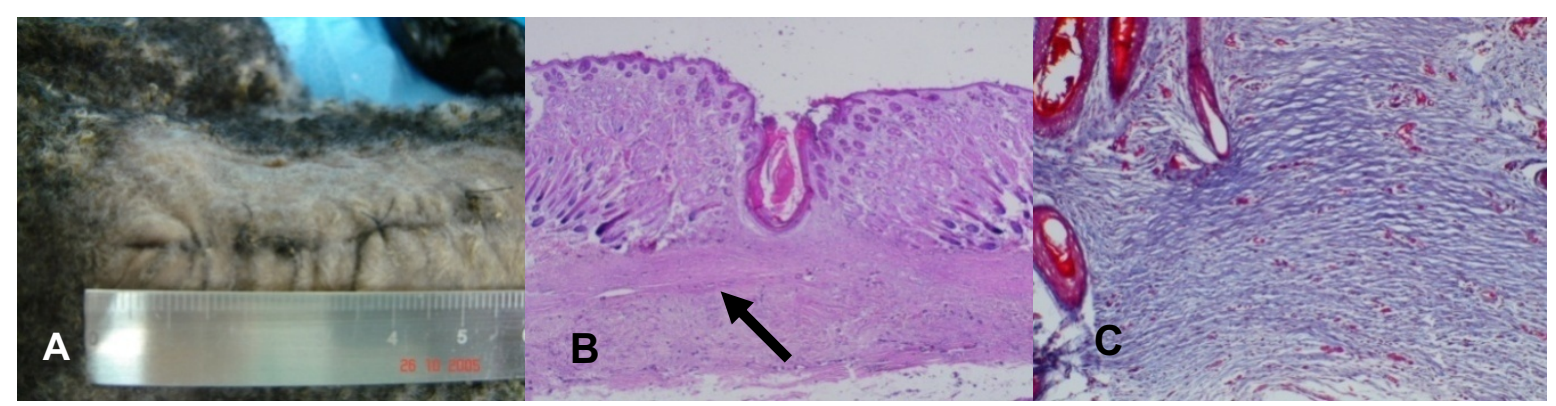

FIGURE 3 - (A) Macroscopic analysis of a skin scar at 140 days of gestation in the case group. (B) Microscopic analysis of hematoxilin/eosin stain-16X stained skin scar, showing an abundance of granular tissue and the patch used (arrow).

(C) Trichrome stain-100X of a mature scar, showing dense collagen, with scattered vascular channels 
There was a statistically significant difference between corrected $(90,9 \%)$ and control groups $(22,3 \%)(p=0,005)$, showing the technique used was successful in the defect's correction. Some cases in this series are included in a previous report ${ }^{27}$.

\section{Discussion}

A large number of studies of fetal surgery for MMC correction have suggested that intrauterine repair can possibly improve clinical outcome $\mathrm{e}^{2-4,7-10,17,18,19}$. Preliminary studies of prenatal MMC defect correction in humans have shown a significant reduction of hindbrain herniation and shunt-dependent hydrocephalus, although preterm delivery remains a major problem ${ }^{23,9,13,20}$. Encouraged by this data, our group proposed the development of a new "easy to apply" technique that could be used in an endoscopic approach. We believe this could decrease the problems found in the open fetal surgery reducing preterm birth and maternal morbidity.

Many animal models where developed to experimentally study spina bifida. The first model was a primate (Macaca mulatta) where a spinal lesion was surgically created and corrected ${ }^{19}$. In 1990, Heffez et al. ${ }^{7}$ working with rats surgically created (on day 18 of a 22-day gestation) a spinal dysraphic lesion that lead to spinal cord damage similar to that seen in human fetuses. The authors proposed the "two-hint hypothesis" for the mechanism of paralysis: a congenital myelodysplasia complicated by an intrauterine spinal cord injury. The same results were found in pigs and other models like the rabbit since then $n^{5,21,22}$. In these studies there was no time interval from the creation of the defect to its correction, so the use of a larger animal model, to permit a prolonged period in utero after surgical manipulation was needed, before extrapolation of these findings to humans. Meuli et al. ${ }^{16}$ demonstrated the similarities between a surgically-created defect in the ovine model and the human MMC. These authors observed that lambs developed lumbar cystic sacs with abnormal spinal cord tissue on the dorsal aspect and histology revealed loss of neural tissue, disruption of neural bundles and areas of cord necrosis in the exposed segments, strikingly similar to that seen in human MMC. Since then many other researchers ${ }^{6,15,17,18}$ have been using and accepting this model for MMC studies. Subsequent sheep studies have shown that if a lumbar myelotomy was added during the creation of the defect also hindbrain herniation, similar to humans would occur. Those authors also showed that in utero closure resulted in reversal of the hindbrain herniation ${ }^{17}$.

The endoscopic approach was first used for treatment of human fetal MMC by Brunner et al. ${ }^{20}$. However this initial effort was of limited success, with placental abruption occurring in 1 case and fetal death occurring in 2 out of 4 cases. We believe that their efforts may have been hindered by their difficult and time consuming closure technique. The simplified method that we present herein may make the endoscopic approach more feasible.

We previously showed that a simplified closing procedure using an interface material to cover defects was successful in a rabbit mode ${ }^{14}$. Here, we extended these studies using sheep fetuses because they are similar to human fetuses in size, anatomy, and gestational duration ${ }^{15,23}$

Yoshizawa et al. ${ }^{10}$ has shown that prenatal MMC correction using a simplified technique with an interface material allows rectal muscle and nerve development that is comparable to that observed following standard neurosurgical repair in sheep. Based on his findings, we hypothised that fetal.

MMC surgery using simplified covering techniques would likely to have results similar to those seen with the standard neurosurgical closure,performed in humans.

The closure technique we presented here to correct MMC-like defects in sheep is relatively simple compared to other techniques reported in the Medline-indexed literature. In Chart 1 we describe in detail all nine techniques we found ${ }^{6,8,10,17,23-26}$ using the fetal sheep as the animal model.

Note that, in some of the studies the defect created included a "complete defect" where the skin, spinal process and duramater where removed, followed by medullar incision. In others, only the skin was removed, without involving muscle or any other planes below this level ${ }^{6,24,25}$. Observe that correction was sometimes performed a few weeks after the defect's creation and sometimes the defect was created and corrected at the same time $^{6,24,25}$.

We believe that some of these techniques, such as the dissection of the latissimus dorsi muscle to cover the lesion ${ }^{8,26}$ or standard neurosurgical closure in several planes ${ }^{10,17}$ are technically difficult to apply endoscopically. Moreover, suturing a patch to the adjacent $\operatorname{skin}^{6,17,18,23}$ would also be difficult and time-consuming to do by fetoscopy. Some of these studies have used glue to affix a maternal skin graft ${ }^{24}$ or patch ${ }^{6,23}$ over the defect. We believe this kind of approach does not seem advisable, given that a major complication after birth is a tethered spinal cord caused by adherence of the medulla to the scar tissue. Moreover, the use of glue can be difficult in the presence of amniotic fluid. In the present study, we circumvented these difficulties by using an interface material.

Another advantage of our technique is that subcutaneous dissection was performed and the interface material could be placed subdermally. This subdermal placement of the interface material enables the lesion to be covered with skin, eliminating the need to affix a patch to an adjacent structure, as done by Eggink et al. ${ }^{6}$, Paek et al. ${ }^{17}$, Bouchard et al. ${ }^{18}$ and Kohl et al. ${ }^{25}$. In initial studies by Copeland et al. ${ }^{24}$ only a skin defect were created to study different materials and techniques for correction. A disadvantage of such an approach is that the direct effects of glue or closure techniques on the medulla itself could not be evaluated. After birth, the spinal cord can become trapped in the scar resulting in a tethered spinal cord. To evaluate this effect, we believe a laminectomy should always be performed, and the various interface materials should be tested prior to $\mathrm{use}^{27}$.

It is important to evaluate mortality associated with defect creation, because the higher the mortality rate is, more animals are needed for the experiment to have statistical strength. We observed a mortality rate of $13 / 36(36.1 \%)$, which is less than the ones reported in other studies (as much as $42 \%)^{16}$. In these studies, the gestational age at which defects have been induced in sheep has varied from 74 to 95 days, we can observe the later the defect is created the less fetal mortality is found. As previously mentioned, the medullar lesion arises from its chemical exposure to the amniotic liquid and from the mechanical trauma of the fetus moving against the uterine wall. The longer the exposure period the more intense the lesion will be, consequently surgeries on later gestational ages, although could reduce mortality, may not reproduce the human pattern of MMC. 
CHART 1 - Summary and schematic representation of published prenatal techniques for correction of MMC-like defects in fetal sheep

\begin{tabular}{|c|c|c|c|c|c|}
\hline 高 & 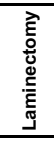 & 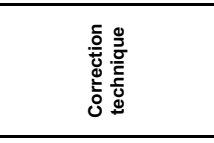 & 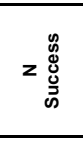 & 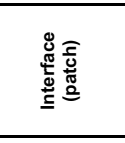 & $\begin{array}{l}\text { Schematic representation of "our } \\
\text { understanding" of the techniques } \\
\text { described }\end{array}$ \\
\hline $\begin{array}{c}\text { Copeland et } \\
\text { al. }^{25}\end{array}$ & $\mathrm{No}^{*}$ & $\begin{array}{l}\text { Maternal skin graft } \\
\text { "glued" to fetal skin } \\
\text { defect }\end{array}$ & $\begin{array}{c}11 \\
(85 \%)\end{array}$ & Not used & \\
\hline $\begin{array}{l}\text { Meuli et } \\
\text { al. }^{26}\end{array}$ & Yes & $\begin{array}{l}\text { Latissimus dorsi flap } \\
\text { flipped over, pulled } \\
\text { though a tunnel, and } \\
\text { placed over the lesion }\end{array}$ & $\begin{array}{c}3 \\
(100 \%)\end{array}$ & Not used & \\
\hline Meuli et al. ${ }^{8}$ & Yes & $\begin{array}{l}\text { Latissimus dorsi flap } \\
\text { flipped over, pulled } \\
\text { though a tunnel, and } \\
\text { placed over the lesion }\end{array}$ & $\begin{array}{c}3 \\
(100 \%)\end{array}$ & Not used & \\
\hline \multirow{2}{*}{ Paek et al. ${ }^{17}$} & \multirow{2}{*}{ Yes } & $\begin{array}{l}\text { Standard neurosurgical } \\
\text { repair }{ }^{\star \star \star}\end{array}$ & \multirow{2}{*}{$\begin{array}{c}14 \\
(100 \%)\end{array}$} & Not used & \\
\hline & & $\begin{array}{l}\text { Simple defect coverage } \\
\text { with patch sutured to } \\
\text { fetal skin }\end{array}$ & & Alloderm® & \\
\hline Kohn et al. ${ }^{26}$ & No & $\begin{array}{c}\text { Skin edges mobilized } \\
\text { with skin sutured over } \\
\text { patch }\end{array}$ & $\begin{array}{c}3 \\
(100 \%)\end{array}$ & eEPTFE & \\
\hline $\begin{array}{l}\text { Bouchard et } \\
\text { al. }^{18}\end{array}$ & Yes & $\begin{array}{l}\text { Skin edges mobilized, } \\
\text { interface sutured over } \\
\text { defect and skin closed } \\
\text { over patch }\end{array}$ & $\begin{array}{c}9 \\
(100 \%)\end{array}$ & XenoDerm® & \\
\hline \multirow[b]{2}{*}{$\begin{array}{l}\text { Yoshizawa } \\
\text { et al. }{ }^{10}\end{array}$} & \multirow[b]{2}{*}{ Yes } & $\begin{array}{c}\text { Standard neurosurgical } \\
\text { repair }\end{array}$ & \multirow[b]{2}{*}{$\begin{array}{l}7 \\
(100 \%)\end{array}$} & Not used & \\
\hline & & $\begin{array}{l}\text { Simple coverage with } \\
\text { patch without suture }\end{array}$ & & $\begin{array}{l}\text { Aloderm } \AA \text { or } \\
\text { GoreTex® }\end{array}$ & \\
\hline \multirow{3}{*}{$\underset{a^{6} .^{6}}{\text { Eggink et }}$} & \multirow{3}{*}{$\mathrm{No}^{* \star}$} & $\begin{array}{l}\text { Simple defect coverage } \\
\text { with patch sutured to } \\
\text { fetal skin } \\
\end{array}$ & \multirow{3}{*}{$\begin{array}{c}11 \\
(68 \%)\end{array}$} & $\begin{array}{l}\text { Collagen } \\
\text { UMC } \\
\text { biomatrix }\end{array}$ & \\
\hline & & Only skin suture & & Not used & \\
\hline & & $\begin{array}{l}\text { Simple defect coverage } \\
\text { with patch sutured to } \\
\text { fetal skin }\end{array}$ & & $\underset{\text { biomatrix® }}{\mathrm{SIS}}$ & \\
\hline \multirow{3}{*}{$\begin{array}{c}\text { Von Koch et } \\
\mathrm{all}^{23}\end{array}$} & \multirow{3}{*}{ Yes } & $\begin{array}{l}\text { Bioglue@ directly } \\
\text { applied to defect }\end{array}$ & \multirow{3}{*}{$\begin{array}{c}3 \\
(100 \%)\end{array}$} & Not used & \\
\hline & & $\begin{array}{l}\text { Bioglue } \Theta+\text { patch with } \\
\text { corner stiches }\end{array}$ & & DuraGen® & \\
\hline & & $\begin{array}{c}\text { Standard } \\
\text { neurosurgical*** }\end{array}$ & & Not used & \\
\hline $\begin{array}{l}\text { Present } \\
\text { study }\end{array}$ & Yes & $\begin{array}{l}\text { Skin edges mobilized } \\
\text { with skin sutured over } \\
\text { patch }\end{array}$ & $9(91 \%)$ & $\begin{array}{c}\text { Biofill@ } \\
\text { Alloderm® }\end{array}$ & \\
\hline
\end{tabular}

*laminectomy performed in only in 2 cases

**laminectomy not performed in 4 cases

***Standard neurosurgical repair: neural placode reformed into a tube, paraspinal muscles partially re -approximated and skin closure
The $91 \%$ correction success rate found in our study fits within the 68 to $100 \%$ success rate range reported in the literature (Chart 1).

The approach examined in the present study has the distinct advantage of producing a relatively good model of the human defect in that it creates an actual spinal defect to be closed. It should also be noted that we obtained a good success rate with a series of two surgeries (lesion induction and correction), while some prior studies included only one surgical episode and/or did not include laminectomy. Future studies should focus on endoscopic application of this technique in order to develop new strategies for endoscopic correction of MMC defects in the human fetus.

\section{Conclusion}

In the present study we describe a simplified technique for correcting MMC-like defects in the ovine fetus.

\section{References}

1. Centers for Disease Control and Prevention (CDC). Prevalence of spina bifida at birth - United States, 19831990: a comparison of two surveillance systems. MMWR Morb Mortal Weekly Rep. 1996;19(45):15-26.

2. Bruner JP, Tulipan N, Paschall RL, Boehm FH, Walsh WF, Silva SR, Hernanz-Schulman M, Lowe LH, Reed GW. Fetal surgery for myelomeningocele and the incidence of shunt-dependent hydrocephalus. J Am Med Assoc. 1999;282:1819-25.

3. Johnson MP, Sutton LN, Rintoul N, Crombleholme TM, Flake AW, Howell LJ, Hedrick HL, Wilson RD, Adzick NS. Fetal myelomeningocele repair: shortterm clinical outcomes. Am J Obstet Gynecol. 2003;189(2):482-7.

4. Meuli M, Meuli-Simmen C, Hutchins GM, Seller MJ, Harrison MR, Adzick NS. The spinal cord lesion in human foetuses with myelomeningocele: implications for fetal surgery. J Pediatr Surg. 1997;32:448-52.

5. Calvano CJ, Reddy PP, Moran ME, Boyle KE, Housley HT, Jennings RW, Harrison MR, Mandell J. Initial studies of holmium: YAG laser creation of spinal defects in fetal rabbits: model for urologic effects of myelomeningocele. J Endourol. 1998;12:199-203.

6. Eggink AJ, Roelofs LAJ, Feitz WFJ, Wijnen RMH, Mullaart RA, Grotenhuis JA, Van Kuppevelt TH, Lammens MMY, Crevels AJ, Hanssen A, Van Den Berg PP: In utero repair of an experimental neural tube defect in a chronic sheep model using biomatrices. Fetal Diagn Ther. 2005;20:335-40.

7. Heffez DS, Aryanpur J, Hutchins, Freeman JM. The paralysis associated with myelomeningocele: clinical and experimental data implicating a preventable spinal cord injury. Neurosurgery. 1990;26:987-92.

8. Meuli M, Meuli-Simmen C, Yingling CD, Hutchins GM, Timmel GB, Harrison MR, Adzick NS. In utero repair of experimental myelomeningocele saves neurological function at birth. J Pediatr Surg. 1996;31(3):397-402. 
9. Tulipan N, Sutton LN, Bruner JP, Cohen BM, Johnson M, Adzick NS. The effect of intrauterine myelomeningocele repair on the incidence of shunt-dependent hydrocephalus. Pediatr Neurosurg. 2003;38:27-33.

10. Yoshizawa J, Sbragia L, Paek BW, Sydorak RM, Yamazaki Y, Harrison MR, Farmer DL. Fetal surgery for repair of myelomeningocele allows normal development of the rectum in sheep. Pediatr Surg Int. 2003;19(3):162-6.

11. Sutton LN. Fetal surgery for neural tube defects. Best Pract Res Clin Obstet Gynaecol. 2008;22(1):175-88.

12. Walsh DS, Adzick NS. Foetal surgery for spina bifida. Semin Neonatol. 2003;8(3):197-205.

13. Bealer JF, Raisanen J, Skarsgard ED, Long SR, Wong K, Filly RA, Adzick NS, Harrison MR. The incidence and spectrum of neurological injury after open fetal surgery. Pediatr Surg. 1995; 30(8):1150-4.

14. Pedreira DAL, Valente PR, Abou-Jamra RC, Pelarigo CL, Silva LM, Goldenberg S. Successful technique to correct a 'myelomeningocele-like' defect in the fetal rabbit. Fetal Diagn Ther. 2003;18:201-6.

15. Pedreira DAL, Sanchez e Oliveira RC, Valente PR, Abou-Jamra RC, Araújo A, Saldiva P H N. Validation of the ovine fetus as an experimental model for the human myelomeningocele defect. Acta Cir Bras. 2007;22:168-73.

16. Meuli M, Meuli-Simmen C, Yingling CD, Hutchins GM, Hoffman KM, Harrison MR, Adzick NS. Creation of myelomeningocele in utero: a model of functional damage from spinal cord exposure in fetal sheep. J Pediatr Surg. 1995;30:1028-32.

17. Paek BW, Farmer D L, Wilkinson CC, Albanese CT, Peacock W, Harrison MR, Jennings RW. Hindbrain herniation develops in surgically created myelomeningocele but is absent after repair in fetal lambs. Am J Obstet Gynecol. 2000;183(5):1119-23.

18. Bouchard S, Davey MG, Rintoul NE, Walsh DS, Rorke LB, Adzick NS. Correction of hindbrain herniation and anatomy of the vermis after in utero repair of myelomeningocele in sheep. J Pediatr Surg. 2003;38(3):451-8.

19. Michejda M. Intrauterine treatment of spina bifida: primate model. Z Kinderchir. 1984;39:259-61.

20. Bruner JP, Richards WO, Tulipan NB, Arney TL. Endoscopic coverage of fetal myelomeningocele in utero. Am J Obstet Gynecol. 1999;180(1):153-8
21. Housley HT, Graf JL, Lipshultz GS, Calvano CJ, Harrison MR, Farmer DL, Jennings RW. Creation of myelomeningocele in the fetal rabbit. Fetal Diagn Ther. 2000;15:272-9.

22. Pedreira DA, Valente PR, Abou-Jamra RC, Pelarigo CL, Silva LM, Goldenberg S. A different technique to create a 'myelomeningocele-like' defect in the fetal rabbit. Fetal Diagn Ther. 2002;17(6):372-6.

23. Von Koch CS, Compagnone N, Hirose S, Yoder S, Harrison MH, Farmer DL. Myelomeningocele. Characterization of a surgically induced sheep model and its central nervous system similarities and differences to the human disease. Am J Obstet Gynecol. 2005;193:1456-62.

24. Copeland ML, Bruner JP, Richards WO, Sundell HW, Tulipan NB. A model for in utero endoscopic treatment of myelomeningocele. Neurosurgery. 1993;33(3):542-4.

25. Kohl T, Hartlage MG, Kiehitz D, Westphal M, Buller T, Achenbach S, Aryee S, Gembruch U, Brentrup A. Percutaneous fetoscopic patch coverage of experimental lumbosacral full-thickness skin lesions in sheep. Surg Endosc. 2003;17(8):1218-23.

26. Meuli-Simmen C, Meuli M, Yingling CD, Hutchins GM, Harrison MR, Buncke HJ, Sullivan KM, Adzick NS. Fetal reconstructive surgery: experimental use of the latissimus dorsi flap to correct myelomeningocele in utero. Plast Reconstr Surg. 1995;96(5):1007-11.

27. Sanchez e Oliveira RC, Pedreira DAL, Valente PR, Abou-Jamra RC, Araújo A, Saldiva P H N. Biosynthetic cellulose induces the formation of a neoduramater following prenatal correction of meningomyelocele in fetal sheep. Acta Cir Bras. 2007;22:174-81.

\section{Acknowledgment}

To Dra. Silvia Rejane Fontoura Herrera for her contribution in the revision of the manuscript.

\section{Co-authors note}

During the revision of this manuscript we sadly lost the first author of this work. This work would also be his $\mathrm{PhD}$ thesis. We would like to acknowledge his enthusiasm and infinite contribution to the study of the subject and to dedicate this paper to his memory.

Conflict of interest: none Financial source: FAPESP (03/07237-4)

\section{Correspondence:}

Denise Araujo Lapa Pedreira

Rua Bagé, 163/182

04012-140 Sao Paulo - SP Brazil

Phone: (55 11)8473-1574

Fax: (55 11)5572-2033

wdpedreira@uol.com.br

\section{How to cite this article}

Abou-Jamra RC, Valente PR, Araújo A, Oliveira RCS, Saldiva PH, Pedreira DAL. Simplified correction of a meningomyelocele-like defect in the ovine fetus. Acta Cir Bras. [serial on the Internet] 2009 May-Jun;24(3). Available from URL: http://www.scielo.br/acb 